\title{
Can zooplankton grazing affect the functional features of phytoplankton in subtropical shallow lakes? - Experiment in situ in the south of Brazil
}

\author{
João Vitor Fonseca da Silva1, ${ }^{*}$, Matheus Tenório Baumgartner ${ }^{2}$, Maria Rosa Miracle $3, \dagger$, Juliana \\ Déo Dias ${ }^{4}$, Luzia Cleide Rodrigues ${ }^{2}$ and Claudia Costa Bonecker ${ }^{1,2}$ \\ 1 Programa de Pós Graduação em Biologia Comparada, Universidade Estadual de Maringá, Avenida Colombo, \\ 5790, 87020-900, Maringá, PR, Brazil. \\ 2 Programa de Pós Graduação em Ecologia de Ambientes Aquáticos Continentais, Universidade Estadual de \\ Maringá, Maringá, PR, Brazil. \\ 3 Departamento de Microbiología y Ecología, ICBiBE, Universidad de Valencia, Burjassot (Valencia), Spain. \\ ${ }^{4}$ Departamento de Oceanografia e Limnologia, Universidade Federal do Rio Grande do Norte, Natal, RN, Brazil. \\ * Corresponding author: joaovitorbio@live.com
}

Received: 31/07/2018 Accepted: 03/04/2019

\begin{abstract}
Can zooplankton grazing affect the functional features of phytoplankton in subtropical shallow lakes? - Experiment in situ in the south of Brazil

Herbivory in aquatic environments reflects the organization of trophic webs as a structuring factor in the communities of primary producers. We experimentally evaluated the influence of grazing by zooplankton and by different predator groups on the abundance and biomass of phytoplankton and morphologically-based functional groups (MBFGs), in a subtropical floodplain shallow lake (Brazil). We tested if different grazing levels modify the structure of the phytoplankton, considering that higher zooplankton abundance reduces the abundance and biomass of phytoplankton and the MBFGs. We used five treatments (5 L) with different zooplankton abundance and five replicas to represent an increasing grazing gradient. Sampling of phytoplankton and zooplankton was carried out after 24 hours, in each treatment. The zooplankton abundance presented significant differences among treatments $(\mathrm{F}=11.79 ; p<0.01)$, showing the evident grazing gradient in the experiment. Rotifers dominated all the treatments, followed by copepods, although their abundance decreased at the end of the experiment. In contrast, cladoceran abundance increased. An inverse and significant relationship was observed between zooplankton and rotifer abundances and MBFG III abundance $\left(\beta=-0.85, p<0.01 ; \mathrm{r}^{2}=0.32 ; \beta=-0.54 ; p<0.01 ; \mathrm{r}^{2}=0.29\right.$, respectively), showing an effective predator-prey interaction. Many positive and significant relationships were also observed among the grazers and the prey. The increase of the abundance and biovolume of phytoplankton was related to the bottom-up mechanisms, the rapid population growth of prey, and the short time of the experiment. The change in the MBFGs' contribution was related to the increase in the zooplankton and group abundance, grazer competition and exploitative competition among the MBFGs. The experiment contributes to the knowledge on an important part of the trophic dynamics among planktonic communities in subtropical floodplain shallow lakes.
\end{abstract}

Key words: experiment, predator-prey, morphologically-based functional groups, bottom-up mechanisms

\section{RESUMO}

O pastoreio de zooplâncton pode afetar as características funcionais do fitoplâncton em lagos rasos subtropicais? - Experimento in situ no sul do Brasil

Herbivoria em ambientes aquáticos reflete a organização de teias tróficas como fator estruturante das comunidades de produtores primários. Nós avaliamos a influência da predação do zooplâncton e dos diferentes grupos sobre a abundância e biomassa de fitoplâncton e grupos morfologicamente funcionais $(M B F G)$, experimentalmente em um lago raso de uma planície de inundação 
subtropical (Brasil). Testamos se diferentes niveis de predação modificam a estrutura do fitoplâncton, considerando que a maior abundância de zooplâncton reduz a abundância e a biomassa do fitoplâncton e dos MBFGs. Foram utilizados cinco tratamentos $(5 \mathrm{~L})$, com diferentes abundâncias de zooplâncton, e cinco réplicas, a fim de representar um gradiente crescente de predação. Amostras de fitoplâncton e zooplâncton foram obtidas após 24 horas, em cada tratamento. A abundância zooplanctônica mostrou diferenças significativas entre os tratamentos $(F=11.79 ; \mathrm{p}<0.01)$, evidenciando o gradiente de predação no experimento. Os rotiferos dominaram todos os tratamentos, seguidos pelos copépodes, embora sua abundância tenha diminuído ao final do experimento. Ao contrário, a abundância de cladóceros aumentou. Relação inversa e significativa foi observada entre abundância de zooplâncton e de rotiferos e a abundância de MBFG III $\left(\beta=-0.85, \mathrm{p}<0.01 ; r^{2}=0.32 ; \beta=-0.54 ; \mathrm{p}<0.01 ; r^{2}=0.29\right.$, respectivamente), mostrando uma eficiente relação predador-presa. Relações positivas e significativas também foram observadas entre os predadores e as presas. O aumento da abundância e do biovolume do fitoplâncton foi relacionado aos mecanismos bottom-up, ao rápido crescimento populacional das presas e o curto tempo do experimento. A mudança da contribuição dos MBFGs foi relacionada ao aumento da abundância do zooplâncton e dos grupos, competição entre predadores, e competição exploratória entre os MBFGs. O experimento contribuiu para o conhecimento de uma parte importante da dinâmica trófica entre comunidades planctônicas em lagos rasos de planície de inundação subtropical.

Palavras chave: experimento, predador-presa, grupos morfologicamente funcionais, mecanismos bottom-up

\section{INTRODUCTION}

Zooplanktonic organisms occupy specific niches, and changes in the dominance pattern of these grazers affect prey populations according to the diet complexity of zooplankton species (DeMott, 1986). In addition, the prey selectivity, which regulates the exploitative competition among phytoplankton species (DeMott, 1989), can also facilitate the uncontrolled growth of undesired populations, such as cyanobacteria, because grazing acts preferably on the more natural competitors (Leitão et al., 2018).

The effect of zooplankton grazing on phytoplankton depends on the composition, density, and body size of grazers (Cyr \& Curtis, 1999; Lacerot et al., 2013). In general, small-sized zooplankton (rotifers, small cladocerans, and nauplii) groups feed on small organisms (Cyr \& Curtis, 1999), while large-sized groups vary their feeding strategy as filter feeders (calanoid copepods and clacocerans), omnivores (cyclopoid copepods and cladocerns) and carnivores (cyclopoid copepods) (Declerck et al., 2007; Özkan et al., 2014; Tõnno et al., 2016). Thus, it can be considered that aquatic trophic webs are strongly influenced by the groups or species that are available for consumption (Modenutti et al., 2003; Qiu et al., 2016). Studies revealed that zooplankton is responsible for consuming most of the phytoplankton productivity that is transferred to other trophic levels (Pfister \& Arndt, 1998; Yang et al.,
2016). Along with feeding preference and selectivity by zooplankton, competition among grazers also affects the structure of prey communities, because changes in the relative abundance among grazers can result in potential different grazing levels (Brooks \& Dodson, 1965).

Therefore, the interaction between zooplankton and phytoplankton controls ecosystem processes such as productivity, energy flow, and nutrient cycling (Quintana et al., 2015). The particular interactions among different species of prey and predators can result in the consumption of different functional groups of prey, with potential effects on ecosystem processes and services. Specifically, rotifers are potential grazers of small organisms (up to $5 \mu \mathrm{m}$ ) with high surface/volume ratio and low nutritional value (Brandl, 2005, Kruk et al., 2010) and, as along with cladocerans, they may graze on medium-sized organisms without specializations represented by many classes (Chlorophyceae, Xanthophyceae, and Zygnemaphyceae) (Colina et al., 2016). Copepods preferentially graze on medium to large-sized unicellular flagellates (up to $11.6 \mu \mathrm{m}$ ) with high nutritional value, and on organisms with low mortality, silicate exoskeleton, and high-density cells (Kruk et al., 2010; Colina et al., 2016).

The lakes of the upper Paraná River floodplain present a great diversity of zooplankton and phytoplankton species, and high trophic complexity (Roberto et al., 2009; Agostinho et al., 2009; 
Lansac-Tôha et al., 2009; Bortolini et al., 2016). However, the structure of trophic interactions in these ecosystems can provide important insights about the drivers of spatial and temporal changes in productivity and energy flow. Therefore, our objective was to evaluate the influence of different grazing levels by zooplankton on the phytoplankton community in floodplain lakes. Specifically, we experimentally assessed how the gradient of abundance of zooplankton and groups (rotifer, cladoceran and copepod) affects the abundance and biovolume of phytoplankton and morphologically-based functional groups (MBFGs) in a subtropical floodplain shallow lake, in the South of Brazil. We tested the hypothesis that higher zooplankton abundance reduces the abundance and biomass of phytoplankton and MBFGs (MBFG I-MBFG VII). Specifically, the response of phytoplankton to grazing is likely to depend on the prevailing group of grazers due to feeding preference and selectivity. The investigations of these biotic relationships between planktonic communities contributes to understanding the trophic dynamics of river-floodplain systems, particularly about the basis of food webs.

\section{MATERIAL AND METHODS}

\section{Experimental Design}

The experiment was conducted in situ, in Garças Lake (22 $2^{\circ} 43^{\prime} 27.18^{\prime \prime} \mathrm{S}$ and $\left.53^{\circ} 13^{\prime} 4.56^{\prime \prime} \mathrm{W}\right)$, which is located in the upper Paraná River floodplain. This lake is $2128 \mathrm{~m}$ in length, with an area of $14 \mathrm{ha}$ and a perimeter of $4338 \mathrm{~m}$. This environment is directly under the influence of water-level variations of the Paraná River, since it is permanently connected to this river.

We conducted the experiment on December 10, 2016 (summer), during a period of 24 hours. The environmental conditions of the lake at the beginning of the experiment were observed: depth $(1.60 \mathrm{~m})$, water temperature $\left(27^{\circ} \mathrm{C}\right), \mathrm{pH}$ (7.36), dissolved oxygen $(2.02 \mathrm{mg} / \mathrm{L})$, electric conductance $(71.80 \mu \mathrm{S} / \mathrm{cm})$, total nitrogen (74.29 $\mu \mathrm{g} / \mathrm{L})$, total phosphorous $(46.90 \mu \mathrm{g} / \mathrm{L})$, nitrate $(14.88 \mu \mathrm{g} / \mathrm{L})$, and phosphate $(6.48 \mu \mathrm{g} / \mathrm{L})$.

The study design involved the manipulation of the abundance of zooplankton, simulating an increasing grazing gradient, considering that the effect of grazing on phytoplankton depends on the community structure of grazers. We used a dilution/concentration technique, which is employed to control the grazing of the zooplankton on primary producers (Landry \& Hassett, 1982; Calbet et al., 2012), and is based on actively manipulating the abundance of zooplankton through sequential dilutions and concentrations of the lake water. This procedure indirectly controls the encounter rate between grazer and prey.

Each sampling unit was composed of a plastic bottle $(5 \mathrm{~L})$, attached to a floater and randomly placed in the lake. This floating structure allowed bottles to stay suspended in the sub-surface, without shading. We had five replicates (bottles) of each of the five treatments representing the grazing gradient (see description below), totalizing 25 sampling units (microcosms).

For the preparation of mesocosms, water was previously collected at many sites within the lake using a water pump, and it was then mixed and stored in a water tank $(500 \mathrm{~L})$ inside the boat. This water represented the observed zooplankton-phytoplankton relationship of the lake and was used in all treatments to ensure the homogeneity of the initial experimental conditions. The dilutions of predators were performed with the water from the tank, and filtered with a planktonic net $(10 \mu \mathrm{m})$ to retain zooplankton. To avoid unpredicted changes in the phytoplankton structure due to a shortage of resources and potential community collapse, we supplied each sampling unit with low-concentration nutrients in the mesocosms $(10 \mu \mathrm{g} / \mathrm{L}$ of nitrate and $0.5 \mu \mathrm{g} / \mathrm{L}$ of phosphate, considering $\mathrm{N}: \mathrm{P}=20: 1$ ).

Samples of phytoplankton and zooplankton obtained from the lake were considered as the communities at the beginning of the experiment. The phytoplankton was collected in $100 \mathrm{~mL}$ of water, fixed with acetic Lugol. The zooplankton was collected from $5 \mathrm{~L}$ of water filtered in a plankton net $(45 \mu \mathrm{m})$, fixed with formalin $40 \%$ buffered with calcium carbonate.

We simulated five different scenarios of the predator-prey relationship; manipulating the zooplankton density through dilution and concentration (the filtration with the $45-\mu \mathrm{m}$ plankton net retained all zooplankton). There- 
fore, treatments represented: (i) dilution of the abundance of grazers to $1 / 4$ of that observed in the lake, or $25 \%$ of grazers (T1), containing $1.25 \mathrm{~L}$ directly from the tank and $3.75 \mathrm{~L}$ of filtered water; (ii) dilution of the abundance of grazers to $1 / 2$ of that observed in the lake, or $50 \%$ of grazers (T2), containing $2.5 \mathrm{~L}$ directly from the tank and 2.5 L of filtered water; (iii) abundance of grazers observed in the lake (T3), with 5 L directly from the tank, without dilution or concentration; (iv) $2 \mathrm{x}$ the abundance of grazers in the lake (T4), containing $10 \mathrm{~L}$ from the tank, concentrated into $5 \mathrm{~L}$ using the plankton net $(45 \mu \mathrm{m})$; and (v) $4 \mathrm{x}$ the abundance of grazers in the lake (T5), containing $20 \mathrm{~L}$ from the tank, concentrated into $5 \mathrm{~L}$ using the plankton net $(45 \mu \mathrm{m})$.

Experimental units were exposed for 24 hours, and then we took samples of $100 \mathrm{~mL}$ of each unit, fixed with acetic Lugol, to analyze phytoplankton qualitatively and quantitatively, and filtered 4.35 L of each sampling unit in a plankton net $(45 \mu \mathrm{m})$, fixed with formalin $40 \%$, to analyze zooplankton. The remaining water of each experimental unit was used to calculate the biovolume.

\section{Analysis of Communities}

The quantitative analysis of the phytoplankton community was performed according to Utermöhl (1958), in an inverted microscope (Carl Zeiss) with a millimetric ocular attached. Counting was carried out in random fields, until the stabilization of the increment of individuals per class, and the result was expressed as individuals (cells, colonies or filaments) per mL. The classification of Cyanobacteria followed Komárek \& Anagnostidis (1986, 1989, 1998, 2005), and other groups followed Reviers (2003). Identified taxa were further classified into seven morphological-functional groups (MBFG) following Kruk et al. (2010), according to the characteristics of each taxon (e. g. presence of aerotopes, flagella, mucilage, heterocyst, presence of silica, and volume). The biomass of phytoplankton $\left(\mathrm{mm}^{3} / \mathrm{L}\right.$ was estimated from the individual biovolume, considering the geometric forms of algal cells, following Hillebrand et al. (1999), Sun \& Liu (2003) and Fonseca et al. (2014). We took measurements of volume, surface, maximum linear dimension, width, and height for each taxon, for a minimum of 50 individuals, or from all individuals when abundance was low.

The identification of the zooplankton species was performed in an optic microscope (Olympus CX41), following specialized literature (Smirnov, 1971, 1976, 1992; Koste, 1978; Elmoor-Loureiro, 1997; Dussart, 1984; Reid 1985). For the information on zooplankton community composition recorded in the experiment (See Table S1, is available at http://www.limnetica.net/en/limnetica). The abundance was estimated by counting at least 50 individuals of each group (rotifers, cladocerans, and copepods), in three sequential sub-samplings (Bottrell et al., 1976), obtained with a Stempell pipette $(2.5 \mathrm{~mL})$, in a Sedgwick-Rafter chamber. Samples with a low number of individuals were quantified entirely and results were expressed as ind/L.

Zooplankton biomass was estimated from the biovolume of rotifers (Ruttner-Kolisco, 1977), the length-weight relationships of microcrustaceans reported for the floodplain (Azevedo et al., 2012), and literature, mostly from tropical regions (Dumont et al., 1975; Melão, 1999; Maia-Barbosa \& Bozelli, 2005). Measurements (length, width, and height) of up to 30 individuals of each species of rotifers, cladocerans, and adult and juvenile copepods, were taken in each sample.

\section{Data analysis}

A one-way Analysis of Variance (ANOVA) was used to test for differences in the abundance of zooplankton (grazers) among treatments (T1 to T5), and thus ensure the efficiency of the experimental design. Data on zooplankton abundances had been transformed previously $(\log (x+1))$.

Simple linear regressions using ordinary least squares (Zar, 2009) were used to evaluate the effect of the grazing gradient of the zooplankton (total abundance and abundance of different groups - rotifers, cladocerans, and copepods) on phytoplankton (total abundance and biovolume from different MBFGs). Data used in regressions were those from the results of each sampling unit, having subtracted the results from lake samples (referential conditions) of predator and prey. These data were transformed $(\log 10(\mathrm{x}+1))$ to 
approximate relationships to linear. Regression models were fitted using function "lm" from the package "stats" in the R Environment (R Core Team, 2013). The assumptions of residual normality and homoscedasticity were tested using Shapiro-Wilk and Levene's test, respectively. Analyses were considered significant at the level of $\alpha=0.05$ and developed using the package "vegan" (Oksanen et al., 2013). Graphs were built in Statistica 7.0 (Statsoft Inc., 2005).

\section{RESULTS}

\section{Phytoplankton and Zooplankton}

The phytoplankton abundance was mainly represented by Chlorophyceae, followed by Cryptophyceae and Cyanobacteria in all treatments, and Zygnemaphyceae in the lake. Considering the biovolume of algae, Cyanobacteria dominated in all experiments, followed by Chlorophyceae, and Bacillariophyceae dominated in the lake (Figs. $1 \mathrm{a}$ and $1 \mathrm{~b}$ ).

The total abundance and especially the biovolume of phytoplankton increased along the grazing gradient and presented very high values when compared to the lake (Figs. 1a and 1b). It was also noted that the contribution of the functional groups varied. MBFG VII had higher biovolume in most of the treatments (T3, T4, and T5) (Fig. 2a) and MBFG V had higher abundance in all treatments (Fig. 2b).

As expected from the experimental design, the abundance of zooplankton presented significant variation along the grazing gradient (ANOVA, $\mathrm{F}(4,2.01)=16.87 ; p<0.01)$. The post-hoc Tukey test revealed that the average abundance of zooplankton in treatment $\mathrm{T} 1$ was significantly different from $\mathrm{T} 4$ and $\mathrm{T} 5$, and that $\mathrm{T} 3$ was different from T5 $(p<0.05)$ (Fig. 3a). We confirmed the efficiency of the dilution/concentration procedure, because the zooplankton abundance was lower in the treatment with more dilution of the predators (T1) and higher in treatments where predators were concentrated (T4 and T5). Rotifers were numerically dominant in all treatments and in the lake, followed by copepods and cladocerans (Figs. 3a and 3b).

Comparing the beginning (lake) and end of the experiment (treatments), similar values
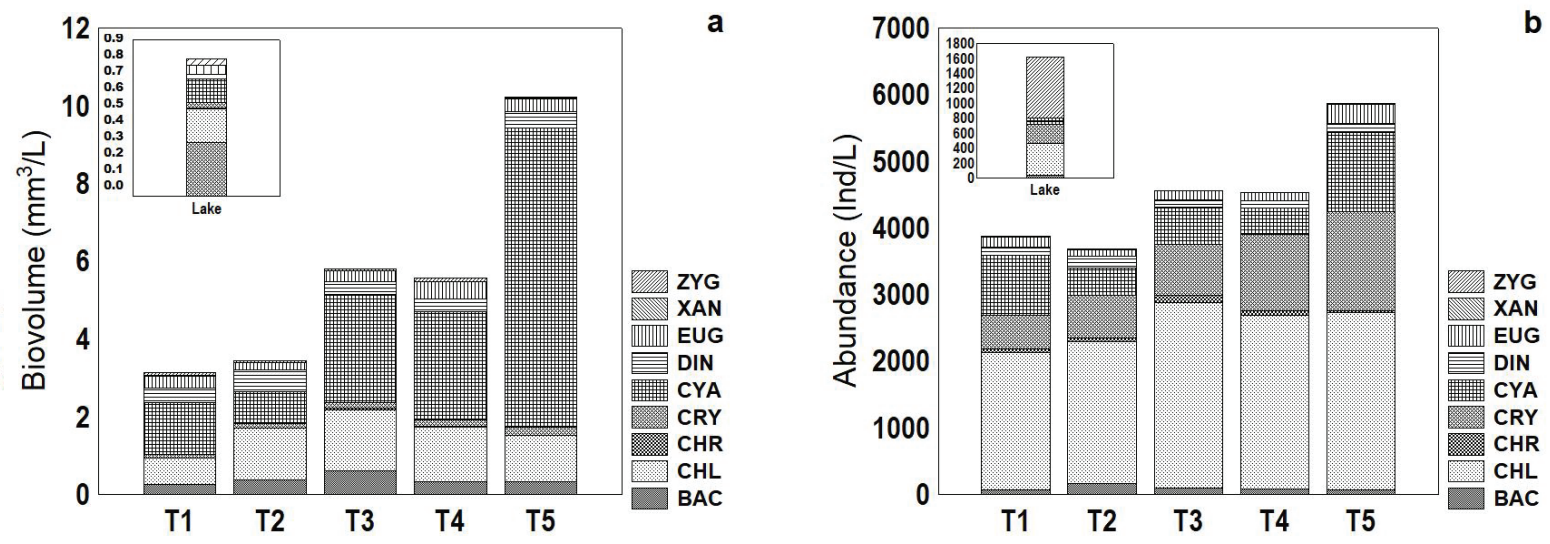

Figure 1. Total (a) abundance (ind/L) and (b) biovolume $\left(\mathrm{mm}^{3} / \mathrm{L}\right)$ of phytoplankton classes observed in the lake (beginning) and in different treatments (end) from the grazing experiment conducted in Garças Lake, in the Upper Paraná river floodplain (Brazil). ZYG = ZYGNEMAPHYCEAE; XAN = XANTHOPHYCEAE; EUG = EUGLENOPHYCEAE; DIN = DINOPHYCEAE; CYA = CYANOBACTERIA; CRY = CRYPTOPHYCEAE; CHR = CHRYSOPHYCEAE; CHL = CHLOROPHYCEAE; BAC $=$ BACILLARIOPHYCEAE. Abundância total (ind/L) (a) e biovolume ( $\mathrm{mm}^{3} / \mathrm{L}$ ) (b) das classes do fitoplâncton observadas na lagoa (início) e em diferentes tratamentos (final) do experimento de predação, realizado na Lagoa das Garças, na planície de inundação do alto rio Paraná (Brasil). ZYG =ZYGNEMAPHYCEAE; XAN =XANTHOPHYCEAE; EUG =EUGLENOPHYCEAE; DIN =DINOPHYCEAE; CYA = CYANOBACTERIA $;$ CRY =CRYPTOPHYCEAE; CHR =CHRYSOPHYCEAE; CHL $=$ CHLOROPHYCEAE; BAC $=$ BACILLARIOPHYCEAE. 

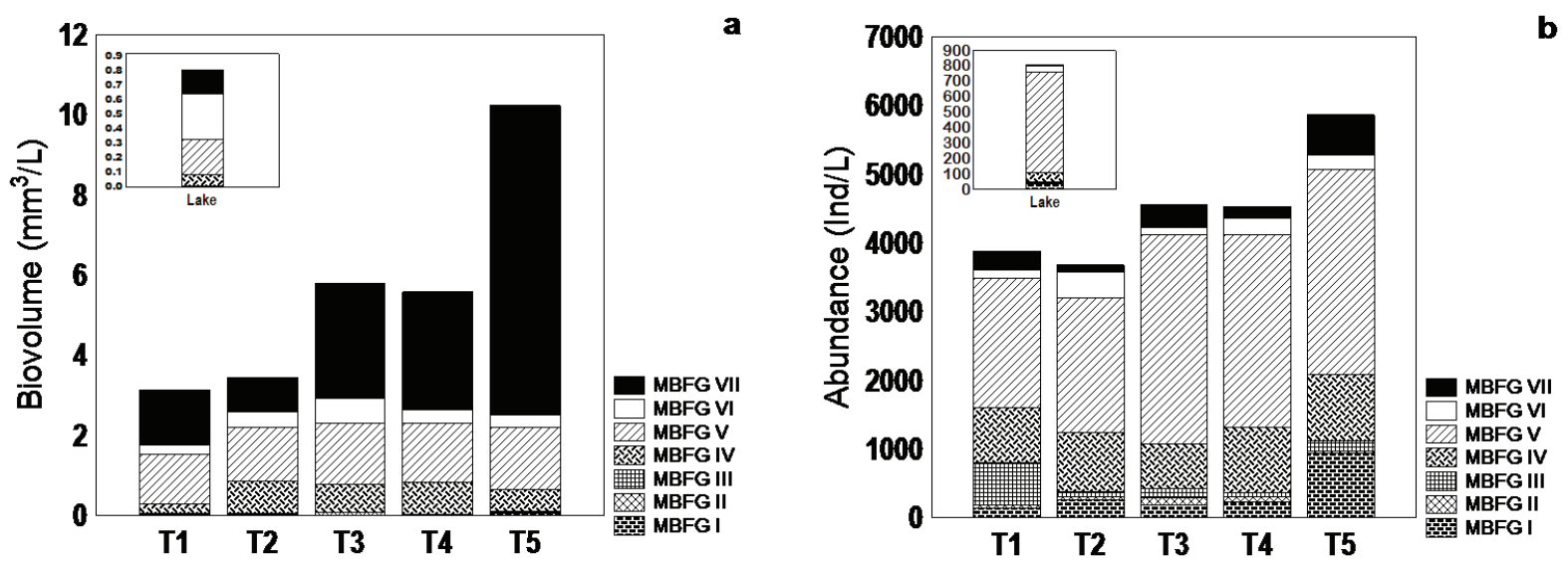

Figure 2. Total and morphologically-based functional groups (MBFG) phytoplankton biovolume (mm $3 / \mathrm{L}$ ) (a) and abundance (ind/L) (b), observed in the lake (beginning) and in different treatments (end) from the grazing experiment conducted in Garças Lake, in the Upper Paraná river floodplain (Brazil). Biovolume total e dos principais grupos morfológicos funcionais (MBFG) do fitoplâncton $\left(\mathrm{mm}^{3} / \mathrm{L}\right)(\mathrm{a})$, e abundância (ind/L) (b), observados na lagoa (início) e em diferentes tratamentos (final) do experimento de predação, realizado na Lagoa Garças, na planície de inundação do alto rio Paraná (Brasil).
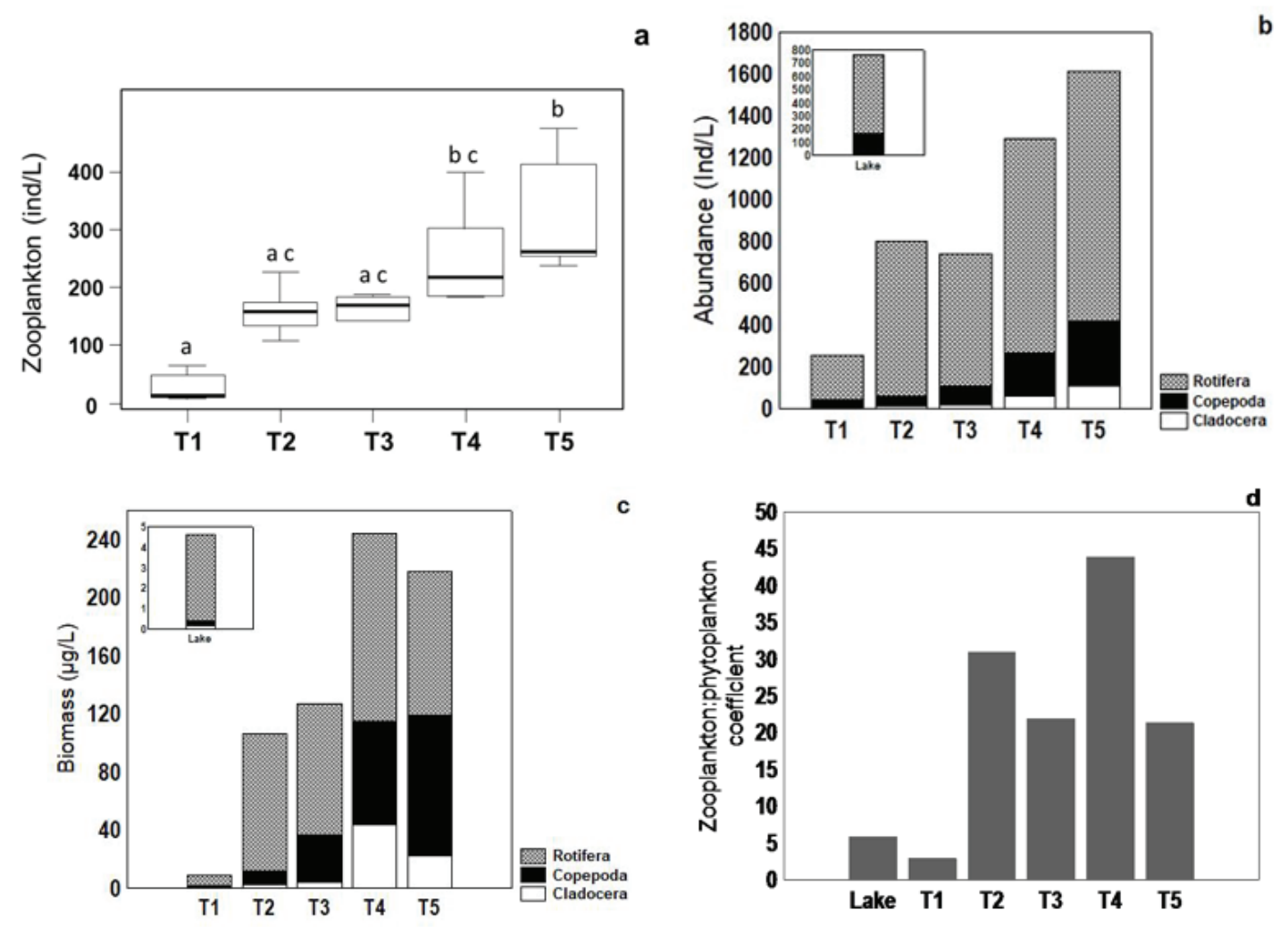

Figure 3. Zooplankton abundance (ind/L) (a) (median (central bar), quartiles (boxes), and range (whiskers), abundance (ind/L) (b) and biomass $(\mu \mathrm{g} / \mathrm{L})$ of the zooplankton groups (c), and zooplankton:phytoplankton coefficient (d) registered in the lake (beginning) and in different treatments (end) from the grazing experiment conducted in Garças Lake, in the Upper Paraná river floodplain (Brazil). Letters in a represent the results of the Tukey test. Abundância do zooplâncton (ind/L) (a) (mediana (barra central), quartis (caixas) e amplitude (whiskers)), abundância (ind/L) (b) e biomassa (c) dos principais grupos zooplanctônicos, e zooplâncton:fitoplâncton coeficiente (d) registradas na lagoa (início) e nos diferentes tratamentos (final) do experimento de predação, realizado na Lagoa Garças, na planície de inundação do alto rio Paraná (Brasil). As letras em a representam os resultados do teste de Tukey. 
were observed in the lake and the treatment with less dilution (T2) and the treatment without manipulating grazers (T3) (Fig. 3b). The higher abundance observed in concentered treatments should already be higher at the beginning. However, the proportion of community abundance between the beginning and the end of the experiment was not maintained. The abundance of rotifers and copepods decreased, and the abundance of cladocerans increased at the end of the experiment, although rotifers continued to dominate.

The zooplankton biomass, as expected, was greater in the concentrated treatments (T4 and T5). Rotifers also showed the highest values in all treatments, cladocerans in $\mathrm{T} 4$ and copepods in $\mathrm{T} 5$ (Fig. 3c).

\section{Responses of Phytoplankton to the Grazing Pressure by Zooplankton}

The gradient of grazing pressure by zooplankton influenced MBFG III (large filaments with aerotopes) because the relationships between the abundance of zooplankton and rotifers and the biovolume of these algae were only significant and inversely related $\left(\beta=-0.85, p<0.01 ; \mathrm{r}^{2}=\right.$ $0.32 ; \beta=-0.54 ; p<0.01 ; \mathrm{r}^{2}=0.29$, respectively) (Table 1).

In contrast, positive and significant relationships were found between (i) the zooplankton abundance and the biovolume of phytoplankton and MBFG IV and MBFG VII; (ii) the rotifer abundance and the biovolume of phytoplankton and MBFG VII; (iii) the cladoceran abundance

Table 1. Linear regression models between the abundance of predators (zooplankton) and features of the prey (phytoplankton) community, from the grazing experiment conducted in Garças Lake, upper Paraná River floodplain (Brazil). $\mathrm{R}^{2}$ is the coefficient of determination, $\beta_{0}$ and $\beta_{1}$ are the intercept and slope coefficient from linear models, respectively, and $p$ is the significance at $\alpha=0.05$. Modelos de regressão linear entre a abundância de predadores (zooplâncton) e características da comunidade de presas (fitoplâncton), a partir do experimento de predação realizado na Lagoa Garças, na planície de inundação do alto rio Paraná (Brasil). $R^{2}$ é o coeficiente de determinação, $\beta_{0}$ e $\beta_{1}$ são o intercepto e o coeficiente de inclinação dos modelos lineares, respectivamente, e p é a significância em $\alpha=0.05$.

\begin{tabular}{clcccc}
\hline \multirow{2}{*}{ Predator } & \multicolumn{1}{c}{ Prey } & $\mathbf{R}^{\mathbf{2}}$ & $\boldsymbol{\beta}_{\mathbf{0}}$ & $\boldsymbol{\beta}_{\mathbf{1}}$ & $\boldsymbol{p}$ \\
\hline Zooplankton (ind/L) & Total biovolume $\left(\mathrm{mm}^{3} / \mathrm{L}\right)$ & 0.248 & -0.124 & 0.184 & 0.011 \\
& MBFG IV biovolume $\left(\mathrm{mm}^{3} / \mathrm{L}\right)$ & 0.166 & -0.030 & 0.032 & 0.043 \\
& MBFG VII biovolume $\left(\mathrm{mm}^{3} / \mathrm{L}\right)$ & 0.246 & -0.215 & 0.180 & 0.011 \\
& MBFG III biovolume $(\mathrm{ind} / \mathrm{L})$ & 0.321 & 3.054 & -0.848 & 0.003 \\
\hline Rotifers (ind/L) & Total biovolume $\left(\mathrm{mm}^{3} / \mathrm{L}\right)$ & 0.172 & 0.067 & 0.103 & 0.030 \\
& MBFG VII biovolume $\left(\mathrm{mm}^{3} / \mathrm{L}\right)$ & 0.179 & -0.032 & 0.103 & 0.030 \\
& MBFG III abundance $(\mathrm{ind} / \mathrm{L})$ & 0.291 & 2.302 & -0.540 & 0.005 \\
\hline Cladocerans (ind/L) & Total Biovolume $\left(\mathrm{mm}^{3} / \mathrm{L}\right)$ & 0.448 & 0.046 & 0.276 & 0.001 \\
& MBFG I biovolume $\left(\mathrm{mm}^{3} / \mathrm{L}\right)$ & 0.324 & -0.001 & 0.004 & 0.002 \\
& MBFG V biovolume $\left(\mathrm{mm}^{3} / \mathrm{L}\right)$ & 0.288 & 0.045 & 0.055 & 0.005 \\
& MBFG VII biovolume $\left(\mathrm{mm}^{3} / \mathrm{L}\right)$ & 0.389 & -0.034 & 0.253 & 0.001 \\
& Total Abundance $(\mathrm{ind} / \mathrm{L})$ & 0.379 & 2.434 & 0.456 & 0.001 \\
& MBFG V abundance $\left(\mathrm{ind}^{2} / \mathrm{L}\right)$ & 0.241 & 2.558 & 0.162 & 0.01 \\
\hline Copepods (ind/L) & Total Biovolume $\left(\mathrm{mm}^{3} / \mathrm{L}\right)$ & 0.438 & -0.117 & 0.291 & 0.001 \\
& MBFG I biovolume $\left(\mathrm{mm}^{3} / \mathrm{L}\right)$ & 0.364 & -0.003 & 0.004 & 0.001 \\
& MBFG V biovolume $\left(\mathrm{mm}^{3} / \mathrm{L}\right)$ & 0.379 & -0.005 & 0.067 & 0.001 \\
& MBFG VII biovolume $\left(\mathrm{mm}^{3} / \mathrm{L}\right)$ & 0.387 & -0.187 & 0.269 & 0.001 \\
& Total Abundance $(\mathrm{ind} / \mathrm{L})$ & 0.345 & 2.187 & 0.463 & 0.002 \\
& MBFG V abundance $\left(\mathrm{mm}^{3} / \mathrm{L}\right)$ & 0.265 & 2.449 & 0.180 & 0.008 \\
\hline
\end{tabular}


and the biovolume of phytoplankton and MBFG I, MBFG V and MBFG VII; (iv) the phytoplankton abundance and MBFG V; and (v) the copepod abundance and the biovolume of phytoplankton and MBFG I, MBFG V and MBFG VII, as well as with the abundance of phytoplankton and MBFG V (Table 1). The zooplankton:phytoplankton coefficient (Jeppesen et al., 2003) was highest in T2 and T4 (Fig. 3d), where MBFG V dominated in the phytoplankton biovolume and abundance, and MBFG VII in the biovolume (Figs. 2a and 2b). More information recorded in the experiment is provided in Fig. S1 (Supplementary Material is available at http://www. limnetica.net/en/limnetica).

\section{DISCUSSION}

The grazing pressure gradient did not affect the phytoplankton abundance and biovolume due to the increase of these attributes in all treatments when compared to the lake. This finding was expected for the dilution treatments but not for the concentrated treatments. The MBFG attributes also increased in the treatments, but their contribution changed. For instance, a greater biovolume of MBFG VI was observed in the lake than in the treatments, and the contribution of MBFG V abundance did not change between the lake and treatments. Therefore, it was not possible to confirm the existence of grazing pressure among the grazers and the prey.

The establishment of the predator-prey relationship depends on the different types of predator in the environment, and also on the feeding selectivity of these organisms and their ability to select, manipulate, and consume prey (Lampert et al.,1986; Hansen et al., 1994). In this context, the inverse relationships between the abundances of zooplankton, rotifers and MBFG III was addressed to the high abundances of small algae (e. g. Pseudoanabena mucicola with $7.5 \mu \mathrm{m} \times 2.5$ $\mu \mathrm{m})$. Thus, small algae should be preferential prey for rotifers, which dominated in the grazer community. The aerotopes, which facilitate floating and make them more accessible as prey in the water column, could have favored grazing (Walsby, 1994). Thus, among the zooplankton, rotifers clearly represented grazing pressure.
In contrast, the many positive and significant relationships observed between the abundance of zooplankton, rotifers, cladocerans and copepods, and the abundance, biovolume, and morphologically-based functional groups of phytoplankton showed a weak predator-prey relationship, which allowed the grazer populations to be maintained at the end of the experiment. These relationships also suggested the direct effect of nutrient release (bottom-up mechanism) overlapping with the predator-prey relationship (top-down mechanism) (Carpenter et al., 1985). The nutrients supplied by the disruption of the algal cells (sloppy feeding) and/or the excretion of nutrients by zooplankton, may have favored the growth of phytoplankton, during the experiment (Oliver et al., 2014). Considering the synergic role of these two mechanisms, some studies state that positive correlations between predator and prey abundances occur when the prey growth rate exceeds the grazing rate, and the growth is limited only by the availability of resources (Pereira et al., 2005). Moreover, the growth of the prey populations is faster than those of the predator.

In our study, the increase in the abundance and biovolume of the morphologically-based functional groups is also supposed to be related to the low efficiency of grazing due to the short duration of the experiment, which possibly did not allow for the growth of grazer populations. Moreover, the low efficiency of grazing may also have influenced the results, and it could be related to the selective pressure on better competitors and/or the morphology of prey, which did not favor grazing (Straile, 1997). For instance, phytoplankton may present protuberances, processes and spines (Padisák et al., 2003) and, in some extreme cases such as cyanobacteria, they present mucilage, which gives them the ability to survive through the digestive system of grazers (Porter, 1976).

The positive and significant relationships between the abundance of zooplankton, rotifers, cladocerans and copepods and the biovolume of MBFG VII, including cyanobacteria (Kruk et al., 2010; Dias \& Huszar, 2011), may be related to the presence of mucilage and/or the size of the colony, which are effective strategies to reduce biomass loss by grazing (Kruk et al., 2017). The reduced grazing of these organisms is a result of 
the decreased efficiency of the filtering apparatus of grazers (Bonecker et al., 2007), which explains the remarkable increase of abundance and biomass for this group of algae in all treatments, when compared to the lake.

The increase in abundances of cladocerans and copepods was related to the increase in the biovolume and abundance of MBFG V, represented by unicellular flagellates of medium to large size (up to $11.6 \mu \mathrm{m})$. Among microcrustaceans, copepods are selective regarding the type of food and are capable of manipulating phytoplankton particles, selecting high-quality cells and eliminating toxic components or those algae that do not provide a high energy gain (DeMott et al., 1991; Russo et al., 2016). An experimental study showed a strong and significant relationship between autotrophic nanoflagellate and copepod abundances, which was attributed to the selective grazing by copepods on medium-sized (20-40 $\mu \mathrm{m})$ ciliates, representing a potential predator for these flagellates (Zöllner, et al., 2003). The biomass of these microcrustaceans also increased where the biovolume and abundance of MBFG V were important to the phytoplankton community, and the zooplankton:phytoplankton ratio was higher.

MBFG IV, represented by medium-sized algae that are palatable for zooplankton, also showed an increased biovolume in most of the treatments. These algae present high energy gain and are potentially predated by cladocerans (Rubenstein \& Koehl, 1977; Colina et al., 2016), which also increased in abundance, when compared to the lake, mainly in the higher grazing treatments. The increase in cladoceran abundance probably influenced the decreased abundance of rotifers and copepods in the same treatments.

Positive and significant relationships observed among cladoceran and copepod abundance and MBFG I biovolume was observed due to the predator-prey relationship. These algae are considered as microphages (very small - up to $5 \mu \mathrm{m}$ - with a high surface/volume ratio), and shwould probably be a preferential prey for cladocerans, represented mainly by small body-size species, and copepods, represented mainly by nauplii. The size of the particles consumed by zooplankton is directly related to their body size (Özkan et al., 2014; Bomfim et al., 2018).

\section{CONCLUSION}

Rotifers dominated the zooplankton community, but their abundance decreased at the end of the experiment, as did the abundance of copepods, while cladoceran abundance increased. The findings suggested competition among these species. Copepods were represented mainly by nauplii and cladocerans by small body-size species. The zooplankton composition did not change in the experiment. The increase in the abundance and biovolume of phytoplankton was related to bottom-up mechanisms, and the change in the MBFGs' contribution was related to the increase in the abundance of zooplankton and groups, competition among grazers and exploitative competition among MBFGs. Only rotifers showed a grazer gradient pressure on small cyanobacteria. Other MBFGs provided a food resource for the microcrustaceans, but their abundance did not decrease. The results allowed us to corroborate our hypothesis partially, and the experiment contributes to the knowledge on an important part of the trophic dynamics among planktonic communities in subtropical floodplain shallow lakes.

\section{ACKNOWLEDGEMENTS}

We thank Leilane Talita Fatoretto Schwind for substantially contributing to the improvement of the manuscript. $\mathrm{CCB}$ received grants from the Conselho Nacional de Desenvolvimento Científico e Tecnológico (CNPq). JVFS and MTB received a scholarship from the Coordenação de Aperfeiçoamento de Pessoal de Nivel Superior (CAPES). Finally, we thank Nupelia (UEM), PELD/CNpq (site 6-PIAP) and Proex/CAPES for logistic and financial supporting.

\section{REFERENCES}

AGOSTINHO, A. A., C. C. BONECKER \& L. C. GOMES. 2009. Effects of water quantity on connectivity: the case of the upper Paraná River floodplain. Ecohydrology \& Hydrobiology, 9 (1): 99-113. DOI: 10.2478/v10104009-0040-x

AZEVEDO, F., J. D. DIAS, L. S. BRAGHIN \& 
C. C. BONECKER. 2012. Length-weight regressions of the microcrustacean species from a tropical floodplain. Acta Limnologica Brasiliensia, 24 (1): 01-11. DOI: 10.1590/ S2179-975X2012005000021

BOMFIM, F. F., L. S. M. BRAGHIN, C. C. BONECKER \& F. A. LANSAC-TOHA. 2018. High food availability linked to dominance of small zooplankton in a subtropical floodplain. International Review of Hydrobiology, 103 (1-2): 26-34. DOI: 10.1002/iroh. 201701923

BONECKER, C. C., M. Y. NAGAE, M. C. M. BLETLLER, L. F. M. VELHO \& F. A. LANSAC-TOHA. 2007. Zooplankton biomass in tropical reservoirs in southern Brazil. Hydrobiologia, 579 (1): 115-123. DOI: $10.1007 / \mathrm{s} 10750-006-0391-\mathrm{X}$

BORTOLINI, J. C., S. TRAIN \& L. C. RODRIGUES. 2016. Extreme hydrological periods: effects on phytoplankton variability and persistence in a subtropical floodplain. Hydrobiologia, 763 (1): 223-236. DOI: 10.1007/s10750-015-2378-y

BOTTREL, H. H., A. DUNCAN, Z. GLIWICZ, E. GRYGIEREK, A. HERZIG, A. HILLBRICHT-ILLKOWSKA, H. KURASAWA, P. LARSSON \& T. WEGLENSKA. 1976. A review of some problems in zooplankton production studies. Norwegian Journal of Zoology, 24 (4): 419-456.

BRANDL, Z. 2005. Freshwater copepods and rotifers: predators and their prey. Hydrobiologia, 546 (1): 475-489. DOI: 10.1007/s10750005-4290-3

BROOKS, J. L. \& S. I. DODSON. 1965. Predation, body size, and composition of plankton. Science, 150 (3692): 28-35.

On line: http://www.jstor.org/stable/ 1717947

CALBET, A., R. A. MARTÍNEZ, S. ISARI, S. ZERVOUDAKI, J. C. NEJSTGAARD, P. PITTA, A. F. SAZHIN, D. SOUSONI, A. GOMES, S. A. BERGER, T. M. TSAGARAKI \& R. PTACNIK. 2012. Effects of light availability on mixotrophy and microzooplankton grazing in an oligotrophic plankton food web: evidences from a mesocosm study in Eastern Mediterranean waters. Journal of
Experimental Marine Biology and Ecology, 424: 66-77. DOI: 10.1016/j.jembe.2012.05.005 CARPENTER, S. R., J. F. KITCHELL \& J. R. HODGSON. 1985. Cascading trophic interactions and lake productivity. BioScience, 35 (10): 634-639. DOI: 10.2307/1309989

COLINA, M., D. CALLIARI, C. CARBALHO \& C. KRUK. 2016. A trait-based approach to summarize zooplankton-phytoplankton interactions in freshwaters. Hydrobiologia, 767 (1): 221-233. DOI: 10.1007/s10750-015-2503-y

CYR, H., \& J. M. CURTIS. 1999. Zooplankton community size structure and taxonomic composition affects size-selective grazing in natural communities. Oecologia, 118 (3): 306-315. DOI: 10.1007/s004420050731

DECLERCK, S., M. VANDERSTUKKEN, A. PALS, K. MUYLAERT \& L. D. MEESTER. 2007. Plankton biodiversity along a gradient of productivity and its mediation by macrophytes. Ecology, 88 (9): 2199-2210. DOI: 10.1890/07-0048.1

DEMOTT, W. R. 1986. The role of taste in food selection by freshwater zooplankton. Oecologia, 69 (3): 334-340. DOI: 10.1007/ BF00377053

DEMOTT, W. R. 1989. Optimal foraging theory as a predictor of chemically mediated food selection by suspension-feeding copepods. Limnology and Oceanography, 34 (1): 140-154. DOI: 10.4319/1o.1989.34.1.0140

DEMOTT, W. R., Q. ZHANG \& W. W. CARMICHAEL. 1991. Effects of toxic cyanobacteria and purified toxins on the survival and feeding of a copepod and three species of Daphnia. Limnology and Oceanography, 36 (7): 1346-1357. DOI: 10.4319/lo.1991.36.7.1346

DIAS, J. B. \& V. L. M HUSZAR. 2011. O papel dos traços funcionais na ecologia do fitoplâncton continental. Oecologia Australis, 15 (4): 799-834. DOI: 10.4257/oeco.2011.1504.04

DUMONT, H. J., I. VAN DE VELDE \& S. DUMONT. 1975. Dry weight estimate of biomass in a selection of cladocera, copepod and rotifera from plankton, periphyton and benthos of continental waters. Oecologia, 19 (1): 75-97. DOI: 10.1007/BF00377592

DUSSART, B. H. 1984. Some Crustacea Copepoda from Venezuela. Hydrobiologia, 23: 
25-67. DOI: 10.1007/978-94-017-3612-1_3

FONSECA, B. M., C. FERRA-GUT, A. TUCCI, L. O. CROSSETI, F. FER-RARI, D. C. BICUDO, C. L. SANT'ANA \& C. E. M. BICUDO. 2014. Biovolume de cianobactérias e algas de reservatórios tropicais do Brasil com diferentes estados tróficos. Hoehnea, 41 (1): 9-30. On line: http://hdl.handle. net $/ 10183 / 112134$

HANSEN, B., P. K. BJORNSEN \& P. J. HANSEN. 1994. The size ratio between planktonic predators and their prey. Limnology and Oceanography, 39 (2): 395-403. DOI: 10.4319/1o.1994.39.2.0395

HILLEBRAND, H., C. DÜSELEN, D. KIRSCHTEL, U. POLLINGHER \& $\mathrm{T}$. ZOHARY. 1999. Biovolume calculation for pelagic and benthic microalgae. Journal of Phycology, 35 (5): 403-424. DOI: 10.1046/j. 1529-8817.1999.3520403.x

INCORPORATION, S. 2005. Statistica for Windows. Tulsa: STATSOFT Inc.

JEPPESEN, E., J. P. JENSEN, C. JENSEN, B. FAAFENG, D. O. HESSEN, M. SØNDERGAARD, T. L. LAURIDSEN, P. BRETTUM \& K. S. CHRISTOFFERSEN. 2003. The impact of nutrient state and lake depth on top-down control in the pelagic zone of lakes: a study of 466 lakes from the temperate zone to the arctic. Ecosystems, 6 (4): 313-325. DOI: 10.1007/PL00021503

KOMÁREK J. \& K. ANAGNOSTIDIS. 1986. Modern approach to the classification system of cyanophytes: chroococcales. Algal Studies, 73 (2): 157-226.

KOMÁREK J. \& K. ANAGNOSTIDIS. 1989. Modern approach to the classification system of cyanophytes: nostocales. Arch. Hydrobiologia, 56 (3): 247-345.

KOMÁREK, J. \& K. ANAGNOSTIDIS. 1998. Cyanoprokaryota - 1. Teil: Chroococcales. Süsswasserfl ora von Mitteleuropa, 19 (1): $1-548$.

KOMÁREK, J. \& K. ANAGNOSTIDIS. 2005. Cyanoprokaryota 2. Teil: Oscillatoriales. Süsswasserflora von Mitteleuropa, 19 (2): $1-759$.

KOSTE, W. 1978. Die Rädertiere Mitteleuropas. Berlin \& Stuttgart, 670 (2): 1-235, 1978
KRUK, C., V. L. HUSZAR, E. T. PEETERS, S. BONILLA, L. COSTA, M. LÜRLING. \& M. SCHEFFER. 2010. A morphological classification capturing functional variation in phytoplankton. Freshwater Biology, 55 (3): 614-627. DOI: 10.1111/j.1365-2427.2009. 02298.x

KRUK, C., M. DEVERCELLI, V. L. M. HUSZAR, E. HERNÁNDEZ, G. BEAMUND, M. DIAZ \& L. H. S. SEGURA. 2017. Classification of Reynolds phytoplankton functional groups using individual traits and machine learning techniques. Freshwater Biology, 62 (10): 1681-1692. DOI: 10.1111/ fwb. 12968

LACEROT, G., C. KRUK, M. LÜRLING \& M. SCHEFFER. 2013. The role of subtropical zooplankton as grazers of phytoplankton under different predation levels. Freshwater Biology, 58 (3): 494-503. DOI: 10.1111/fwb.12075

LAMPERT, W., W. LAMPERT, H. RAI \& B. E. TAYLOR. 1986. Phytoplankton control by grazing zooplankton: a study on the spring clear-water phase. Limnology and Oceanography, 31 (3): 478-490. DOI: 10.4319/lo.1986. 31.3.0478

LANDRY, M. R. \& R. P. L. HASSETT. 1982. Estimating the grazing impact of marine micro-zooplankton. Marine biology, 67 (3): 283-288. DOI: 10.1007/BF00397668

LANSAC-TÔHA, F. A., C. C. BONECKER, L. F. M. VELHO, N. R SIMÕES, J. D. DIAS, G. M. ALVEZ \& E. M. TAKAHASHI. 2009. Biodiversity of zooplankton communities in the Upper Paraná River floodplain: interannual variation from longterm studies. Brazilian Journal of Biology, 69 (2): 539-549. DOI: 10.1590/S1519-69842009000300009

LEITÃO, E., K. A. GER, \& R. PANOSSO. 2018. Selective grazing by a tropical copepod (Notodiaptomus iheringi) facilitates Microcystis dominance. Frontiers in Microbiology, 9 (301): 1-11. DOI: 10.3389/fmicb.2018.00301

ELMOOR-LOUREIRO, L. M. A. 1997. Manual de identificação de cladóceros límnicos do Brasil. Editora Universa, Brasília.

MAIA-BARBOSA, P. M. \& R. L. BOZELLI. 2005. Length-weight relationships for five Cladoceran species in an Amazonian lake. 
Brazilian Archives of Biology and Technology, 48 (2): 303-308. DOI: 10.1590/S151689132005000200018

MELÃO, M. G. G. 1999. A produtividade secundária do zooplâncton: métodos, implicações e um estudo na Lagoa Dourada. Ecologia de reservatórios: estrutura, função $e$ aspectos sociais. 151-183. FAPESP e FUNDBIO, Botucatu - SP.

MODENUTTI, B., C. QUEIMALIÑOS, E. BALSEIRO \& M. REISSIG. 2003. Impact of different zooplankton structures on the microbial food web of a South Andean oligotrophic lake. Acta Oecologica, 24: 289-298. DOI: 10.1016/S1146-609X(03)00030-4

ÖZKAN, K., E. JEPPESEN, T. A. DAVIDSON, M. SØNDERGAARD, T. L. LAURIDSEN, R. BJERRING, L.S. JOHANNSON \& J. C. SVENNING. 2014. Cross-taxon congruence in lake plankton largely independent of environmental gradients. Ecology, 95 (10): 2778-2788. DOI: 10.1890/13-2141.1

OKSANEN, J., F. G. BLANCHET, R. KINDT, P. LEGENDRE, P. R. MINCHIN, R. B. O'HARA \& M. J. OKSANEN. 2013. Package 'vegan'. Community ecology package, version, 2 (9).

OLIVER, S. K., D. K. BRANSTRATOR, T. R. HRABIK, S. J. GUILDFORD \& R. E. HECKY. 2014. Nutrient excretion by crustacean zooplankton in the deep chlorophyll layer of Lake Superior. Canadian Journal of Fisheries and Aquatic Sciences, 72 (3): 390-399. DOI: 10.1139/cjfas-2014-0209

PADISÁK, J., E. SORÓCZKI-PINTÉR \& Z. REZNER. 2003. Sinking properties of some phytoplankton shapes and the relation of form resistance to morphological diversity of plankton-an experimental study. Hydrobiologia, 171: 243-257. DOI: 10.1007/978-94007-1084-9 18

PEREIRA, D. G., L. F. M. VELHO, T. A. PAGIORO \& F. A. LANSAC-TÔHA. 2005. Abundância de nanoflagelados heterotróficos no plâncton de reservatórios com distintos graus de trofia. Acta Scientiarum Biological Sciences, 27 (1): 43-50. DOI: 10.4025/ actascibiolsci.v27i1.1358

PFISTER, G. \& H. ARNDT. 1998. Food selectiv- ity and feeding behaviour in omnivorous filter-feeding ciliates: a case study for Stylonychia. European Journal of Protistology, 34 (4): 446-457. DOI: 10.1016/S0932-4739(98) 80013-8

PORTER, K. G. 1976. Enhancement of algal growth and productivity by grazing zooplankton. Science, 192: 1332-1334. DOI: 10.1126/ science.192.4246.1332

QIU, L., H. CUI, J. WU, B. WANG, Y. ZHAO, J. LI, L. JIA \& Z. WEI. 2016. Snowmelt-driven changes in dissolved organic matter and bacterioplankton communities in the Heilongjiang watershed of China. Science of The Total Environment, 556: 242-251. DOI: 10.1016/j.scitotenv.2016.02.199

QUINTANA, X. D., M. ARIM, A. BADOSA, J. M. BLANCO, D. BOIX, S. BRUCET, \& S. GASCÓN. 2015. Predation and competition effects on the size diversity of aquatic communities. Aquatic Sciences, 77 (1): 45-57. DOI: $10.1007 / \mathrm{s} 00027-014-0368-1$

REID, J. W. 1985. Chave de identificação e lista de referências bibliográficas para as espécies continentais sul-americanas de vida livre da Ordem Cyclopoida (Crustacea, Copepoda). Bolm Zool, 9: 17-143. DOI: 10.11606/issn. 2526-3358.bolzoo.1985.122293

REVIERS, B. D. 2003. Biologie et phylogénie des algues, tome 1. Éditions Belin, Paris, France.

ROBERTO, M. C., N. F. SANTANA \& S. M. THOMAZ. 2009. Limnology in the Upper Paraná River floodplain: large-scale spatial and temporal patterns, and the influence of reservoirs. Brazilian Journal of Biology, 69 (2): 717-725. DOI: 10.1590/S151969842009000300025

RUBENSTEIN, D. I. \& M. A. R. KOEHL. 1977. The mechanisms of filter feeding: some theoretical considerations. The American Naturalist, 111 (981): 981-994. DOI: 10.1086/283227

RUSSO, E., K. FRANKE, H. HAGER, B. ESPINASSE, H. STINOR \& S. SCHULTES. 2016. Modifying the functional diversity in the zooplankton assemblage of an oligotrophic lake differentially affects pelagic community structure and biomass. Food Webs, 8: 23-31. DOI: 10.1016/j.fooweb.2016.07.003 
RUTTNER-KOLISKO, A. 1977. Suggestions for biomass calculations of planktonic rotifers. Archiv fur Hydrobiologie Beihefte, 21: 71-76.

SMIRNOV, N. N. 1971. Chydoridae of the world's fauna. Fauna USSR, Rakoobraznye. Nauka, Leningrad, 1: 531

SMIRNOV, N. N. 1976. Macrothricidae and Moinidae of the world. Fauna USSR, Rakoobraznye. Nauka, Leningrad. 1: 236

SMIRNOV, N. N. 1992. The Macrothricidae of the World. Guides to the Identification of the Microinvertebrates of the continental waters of the world. The Hague. SPB Publishers. 1: 143

STRAILE, D. 1997. Gross growth efficiencies of protozoan and metazo-an zooplankton and their dependence on food concentration, predator-prey weight ratio, and taxonomic group. Limnology and Oceanography, 42 (6): $\quad 1375-1385$. DOI: $10.4319 / 1$. 1997.42.6.1375

SUN, J. \& D. LIU. 2003. Geometric models for calculating cell biovolume and surface area for phytoplankton. Journal of Plankton, 25 (11): 1331-1346. DOI: 10.1093/plankt/fbg096 TÕNNO, I., H. AGASILD., T. KÕIV, R. FREIBERG, P. NÕGES \& T. NÕGES. 2016. Algal Diet of Small-Bodied Crustacean Zooplank- ton in a Cyanobacteria-Dominated Eutrophic Lake. Plos one, 11 (4): 1-17. DOI: 10.1371/ journal.pone.0154526

UTERMÖHL, H. 1958. Zur Vervollkommnung der quantitativen Phytoplankton-Methodik: Mit 1 Tabelle und 15 abbildungen im Text und auf 1 Tafel. Internationale Vereinigung für Theoretische und Angewandte Limnologie: Mitteilungen, 9 (1): 1-38. DOI: 10.1080/ 05384680.1958.11904091

WALSBY, A. E. 1994. "Gas Vesicles”. Microbiology and Molecular Biology Reviews, 58 (1): 94-144.

YANG, E. J., Y. JIANG \& S. LEE. 2016. Microzooplankton herbivory and community structure in the Amundsen Sea, Antarctica. Deep Sea Research Part II: Topical Studies in Oceanography, 123: 58-68. DOI: 10.1016/j. dsr2.2015.06.001

ZÖLLNER, E., B. SANTER, M. BOERSMA, H. G. HOPPE \& K. JÜRGENS. 2003. Cascading predation effects of Daphnia and copepods on microbial food web components. Freshwater Biology, 48 (12): 2174-2193. DOI: 10.1046/j. 1365-2426.2003.01158.x

ZAR, J. H., 2009. Biostatistical Analysis. Prentice Hall, New Jersey.

Con el apoyo de:
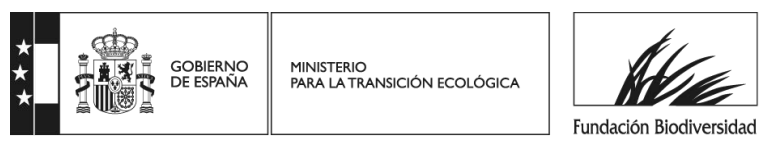